\title{
PENGARUH TINGKAT INFLASI, SUKU BUNGA DAN NILAI KURS DOLLAR AS TERHADAP INDEKS HARGA SAHAM GABUNGAN PADA BURSA EFEK INDONESIA (BEI) PERIODE 2011-2015
}

\author{
Vira Yulia Viska, Aminar Sutra Dewi \\ Sekolah Tinggi Ilmu Ekonomi KBP \\ virayuliaviska26071995@gmail.com
}

\begin{abstract}
This research conducted to find out either simultaneously or partially the influence of the inflation rate, the interest rate and the exchange rates of the US Dollar on composite stock price indeks in Indonesia Stock Exchange. This type or research is quantitative research. Data analysis technique used is multiple linear regression using the program eviews. The results of this study indicite that : 1) inflation rate variable has negative effect that is not significant to composite stock price indeks, 2) the interest rate variable has negative effect significantly to composite stock price indeks, 3) the exchange rates of the US Dollar variable effect significantly positive to the exchange rates of the US Dollar. Determination of coefficient test result shows that the three variable used may explain the variable composite stock price indeks 40,86\% while the remaining 59,14\% influenced by other variables outside this research model.
\end{abstract}

Keyword : Composite Stock Price Indeks, Inflation Rate, Interest Rete and Exchange Rates Of The US Dollar

\section{PENDAHULUAN}

Pasar modal merupakan salah satu instrumen ekonomi dewasa ini yang mengalami perkembangan sangat pesat. Pasar modal merupakan indikator kemajuan perekonomian suatu negara serta menunjang ekonomi negara yang bersangkutan (Robert, 1997). Pasar modal memilki peran penting bagi perekonomian suatu negara. Dengan adanya pasar modal (capital market), investor yang sebagai pihak yang memiliki kelebihan dana dapat menginvestasikan dananya pada berbagai sekuritas dengan harapan memperoleh imbalan (return). Sedangkan bagi perusahaan sebagai pihak yang memerlukan dana dapat memanfaatkan dana tersebut untuk mengembangkan proyekproyeknya. Dengan alternatif pendanaan dari pasar modal, perusahaan dapat beroperasi dan mengembangkan bisnisnya dan pemerintah dapat membiayai berbagai kegitannya sehingga meningkatkan kegiatan perekonomian negara. (Tandelilin, 2010)

Kegiatan investasi adalah kegiatan menanamkan atas sejumlah dana baik langsung maupun tidak langsung dengan tujuan memperoleh keuntungan dimasa depan. Salah satu kegiatan yang dapat dipilih oleh investor adalah berinvestasi di 
pasar modal. Di indonesia, investor yang berminat untuk berinvestasi di pasar modal dapat berinvestasi di Bursa Efek Indonesia (BEI).

Bursa Efek Indonesia mempunyai satu indikator indeks yang sering diperhatikan investor ketika berinvestasi di Bursa Efek Indonesia adalah Indeks Harga Saham Gabungan. Indeks Harga Saham Gabungan dapat menjadi leading indicator economic pada suatu negara. Pergerakan pasar yang sedang mengalami peningkatan atau mengalami penurunan dapat dilihat dari nilai-nilai saham yang tercatat dan tercermin melalui pergerakan indeks atau lebih dikenal dengan Indeks Harga Saham Gabungan (IHSG). Indeks Harga Saham Gabungan atau Composite Stock Price Indeks (IHSG) merupakan suatu nilai yang digunakan untuk mengukur kinerja kerja saham yang tercatat di suatu bursa efek. IHSG dapat mencerminkan bursa efek, apakah pasar sedang dalam keadaan bullish (harga saham cenderung bergerak naik) atau dalam keadaan bearish (harga saham cenderung bergerak turun).

Di dalam pasar modal terdapat beberapa variabel yang juga ikut serta dalam mempengaruhi Indeks Harga Saham Gabungan (IHSG) antara lain adalah Tingkat Inflasi, Suku Bunga, Nilai Tukar Rupiah pada US Dollar.

Tingginya tingkat inflasi dapat menurunkan daya beli masyarakat dan juga meningkatnya harga faktor produksi. Hal itu biasanya akan berdampak pada anggapan pesimis mengenai prospek perusahaan yang menghasilkan barang atau jasa yang terkena dampak inflasi sehingga dapat mempengaruhi penawaran harga saham perusahaan tersebut dan pada akhirnya berakibat pada pergerakan indeks harga saham di BEI.

Tingkat suku bunga juga merupakan salah satu variabel yang dapat mempengaruhi harga saham. Kenaikan suku bunga yang agresif bisa memperkuat rupiah, tapi Indeks Harga Saham Gabungan (IHSG) akan anjlok karena investor akan memilih menabung di bank. Apabila suku bunga mengalami peningkatan maka harga saham akan mengalami penurunan.

Terdapat alternatif investasi lain yang juga dapat mempengaruhi transaksi saham di bursa efek, yakni investasi pada valuta asing dalam hal ini adalah dollar (USD). Kurs mempengaruhi kompetitif suatu perusahaan karena perubahan kurs diikuti perubahan nilai tukar pendapatan dan biaya operasional perusahaan, sehingga peruahan kurs secara langsung mempenngaruhi perubahan harga saham.

Indeks Harga Saham Gabungan mengalami peningkatan yang semakin pesat sejak krisis ekonomi yang melanda Indonesia pada tahun 1998. Hal ini ditunjukkan dari perkembangan nilai IHSG dan nilai transaksi. Nilai IHSG mengalami peningkatan hingga 470 persen dari tahun 2003 sampai akhir tahun 2007. Namun krisis ekonomi global mulai awal 2008 bedampak pada pasar modal indonesia. Tercermin dari jatuhnya nilai IHSG sebesar 61,62 persen dalam kurun waktu yang relatif singkat (satu tahun) dan telah mengakibatkan para investor baik itu dari dalam maupun luar negeri lebih berhati-hati dalam menginvestasikan dananya terutama di pasar modal indonesia. (Hartono,2013).

Fenomena adanya dua krisis dunia yang hampir bersamaan yaitu berkisar pada pertengahan tahun 2015 dimana Yunani dan serta China sama-sama mengalami krisis yang juga sangat berdampak negatif untuk Indonesia, IHSG Fluktuatif bergerak naik dan turun secara tajam merespons perkembangan 
penanganan krisis Eropa pada tahun 2015 lalu. (Dewantoro,2014). Penurunan Indeks Harga Saham Gabungan pada tahun 2015 bukan hanya disebabkan oleh Yunani dan China tapi terjadi akibat adanya spekualsi mengenai kebijakan yang akan diambil bank sentral AS atau The FED di tahun 2015 yang berkaitan dengan kenaikkan tingkat suku bunga dan menguatanya dollar AS sehingga investor menjadikan dollar AS sebagai salah satu investasi secara fisik yang dapat digunakan pada kondisi tersebut. Keadaan seperti ini yang menyebabkan Penurunan Indeks Harga Saham Gabungan pada tahun 2015 dimulai pada pertengan bulan Agustus 2015 di BEI.

Berdasarkan latar belakang di atas, maka peneliti tertarik untuk meneliti tentang Pengaruh Tingkat Inflasi, Suku Bunga Dan Nilai Kurs Dollar Terhadap Indeks Harga Saham Gabungan Pada Bursa Efek Indonesia (BEI) Periode 20112015.

Rumusan Masalah

1. Apakah ada pengaruh Tingkat Inflasi terhadap Indeks Harga Saham Gabungan (IHSG)

2. Apakah ada pengaruh Suku Bunga terhadap Indeks Harga Saham Gabungan (IHSG)

3. Apakah ada pengaruh Nilai Kurs Dollar terhadap Indeks Harga Saham Gabungan (IHSG).

\section{LANDASAN TEORI DAN HIPOTESIS}

\section{A. Indeks Harga Saham Gabungan}

Indeks Harga Saham Gabungan atau Composite Stock Price Index (IHSG) merupakan suatu nilai yang digunakan untuk mengukur kinerja kerja saham yang tercatat di suatu bursa efek. Seperti di mayoritas busra-busra dunia, Indeks yang ada di BEI dihitung dengan menggunakan metodologi rata-rata tertimbang berdasarkan jumlah saham tercatat (nilai pasar) atau Market Value Weighted Average Index.

\section{B. Inflasi}

Menurut Kuncoro (2011) tingkat inflasi adalah kecenderungan dari harga untuk meningkat secara umum dan terus menerus. Kenaikan harga dari satu atau dua barang tidak dapat disebut Inflasi, kecuali bila kenaikan tersebut meluas atau mengakibatkan kenaikan kepada barang lainnya. Menurut Boediono (1998) definisi singkat dari Inflasi adalah kecenderungan dari harga-harga untuk menaik secara umum dan terus menerus. Kenaikan harga dari satu atau dua barang saja tidak disebut Inflasi. Syarat adanya kecenderungan menaik yang terus menerus juga perlu digaris-bawahi.

Menurut Putong (2002), Inflasi dibedakan atas tiga jenis, antara lain: Menurut Sifatnya, Inflasi jika dilihat dari penyebabnya dan Inflasi dibagi menjadi dua jika dilihat dari asalnya.

\section{Suku Bunga}

Menurut Wibowo dan Suhendra (2010) bahwa tingkat suku bunga digunakan pemerintah untuk mengendalikan tingkat harga, ketika tingkat harga tinggi dan jumlah uang yang beredar dalam masyarakat banyak sehingga konsumsi 
masyarakat tinggi akan diantisipasi oleh pemerintah dengan menetapkan tingkat suku bunga yang tinggi.

Tingkat suku bunga dapat didefinisikan sebagai tingkat pengembalian aset yang mempunyai risiko mendekati nol. Investor dapat menggunakan tingkat bunga sebagai patokan (benchmark) untuk perbandingan bila ingin berinvestasi.

Menurut Tandelilin (2010) bahwa tingkat suku mempengaruhi harga saham secara terbalik (Cateris Paribus). Bila pemerintah mengumumkan tingkat suku bunga yang lebih tinggi maka investor akan menjual sahamnya dan beralih berinvestasi pada sektor perbankan seperti deposito dan tabungan.

\section{Nilai Kurs}

Kurs valuta asing atau kurs uang asing menujukkan harga atau nilai mata uang sesuatu negara dinyatakan dalam nilai mata uang negara lain. Kurs valuta asing dapat juga didefinisikan jumlah uang domestik yang dibutuhkan, yaitu banyaknya rupiah yang dibutuhkan untuk memper oleh satu unit mata uang asing. Pertukaran antara dua mata uang yang berbeda dimana akan terdapat perbandinagan nilai atau harga antara kedua mata uang tersebut. Perbandingan nilai inilah yang disebut kurs. Kurs valuta adalah harga satu unit valuta yang ditunjukkan dalam valuta lain. (Sukirno, 2010).

\section{Kerangka Konseptual}

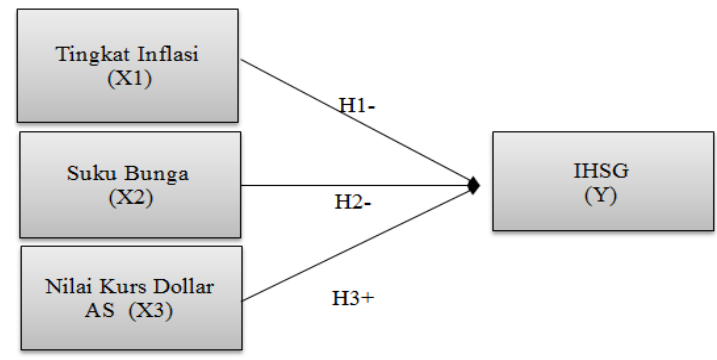

\section{Hipotesis Penelitian}

Ha1 :Tingkat Inflasi berpengaruh negatif dan tidak signifikan terhadap indeks harga saham gabungan (IHSG).

Ha2 :Suku Bunga berpengaruh negatif signifikan terhadap Indeks Harga Saham Gabungan (IHSG).

Ha3 :Nilai kurs Dollar AS berpengaruh positif signifikan terhadap Indeks Harga Saham Gabungan (IHSG).

\section{METODE PENELITIAN}

\section{Jenis Penelitian}

Jenis penelitian yang ada dalam penelitian ini adalah penelitian kuantitatif.

\section{Jenis dan sumber data}

Jenis data yang digunakan peneliti dalam penelitian ini adalah data kuantitatif time seris ( runtut waktu) yang bersumber dari data sekunder, yaitu data yang diperoleh secara tidak langsung atau melalui informasi yang yang didapatkan dari buku, dokumen, maupun situs lembaga tertentu. Dalam penelitin ini data IHSG bersumber dari informasi http://.yahoofinance.com anuualy 2011-2015, dan data tingnkat inflasi, suku bunga dan nilai kurs yang bersumber dari Bank Indonesia www.bi.go.id. Jumlah data ada setiap bulan 
selama 5 tahun sehingga ada 60 data Tingkat Inflasi, Tingkat Suku, Nilai Kurs Dollar AS dan Indeks Harga Saham Gabungan.

\section{Teknik pengumpulan data}

Dalam pengumpulan data penulis menggunakan teknik dokumentasi dengan mengumpulkan data, bukti, dan keterangan.

\section{Definisi Operasional Variabel \\ a. Indeks Harga Saham Gabungan (Y)}

Indeks Harga saham Gabungan (IHSG) adalah indeks harga yang merupakan gabungan semua harga saham yang tercatat di Bursa Efek Indonesia (BEI), Dalam penelitian ini data IHSG yang digunakan adalah indeks harga saham setiap bulan dihitung menggunakan harga saham terakhir (closing price) yang dipublikasikan oleh Bursa Efek Indonesia pada periode tahun 2011-2015. Pengukuran yang digunakan dalam Rp/\$ USD.

\section{b. Tingkat Inflasi (X1)}

Tingkat Inflasi merupakan proses kenaikkan harga barang-barang pada umumnya secara terus menerus selama periode tertentu. Data yang digunakan peneliti dalam penelitian ini adalah data inflasi diperoleh dari laporan inflasi tiap akhir bulan yang telah ditetapkan oleh Bank Indonesia mulai bulan Januari 2011 sampai akhir Desember 2015. Pengukuran yang digunakan adalah satuan persen.

\section{c. Tingkat Suku Bunga (X2)}

Data yang digunakan untuk menghitung suku bunga dalam penelitian ini adalah data suku bunga Bank Indonesia (BI Rate) tiap akhir bulan yang telah ditetapkan oleh Bank Indonesia mulai dari bulan Januari 2011 sampai akhir Desember 2015. Pengukuran yang digunakan adalah satuan persen.

\section{d. Nilai Kurs Dollar AS (X3)}

Dalam peneliti ini data Nilai Kurs Dollar AS yang digunakan adalah kurs dollar yang dihitung berdasarkan kurs tengah, berdasarkan kurs jual dan kurs beli disetiap akhir bulan Januari 2011 sampai akhir Desember 2015 yang telah ditetapkan oleh Bank Indonesia. Pengukuran yang digunakan dalam $\mathrm{Rp} /$ USD.

\section{Teknik Analisa Data}

\section{Analisa Statistik Deskriptif}

Uji statistik deskriptif berkenaan dengan bagaimana data dapat digambarkan/dideskripsikan, baik secara numerik misalnya menghitung rata-rata, standar deviasi atau secara grafis dalam bentuk tabel atau grafik.

\section{2. uji stasioneritas}

Stasioner merupakan suatu kondisi data time series yang jika rata-rata, varian dan covarian dari perubah tersebut seluruhnya tidak dipengaruhi oleh waktu (Junaidi, 2103). Model pengujian stasioneritas dan akar unit yang akan digunakan disini adalah metode Augmented Dickey Fuller (ADF) dan Philips Perron (PP). Prosedur untuk mengetahui data stasioner atau tidak dengan cara membandingkan antara nilai statistik ADF atau PP dengan nilai kritis distribusi Mac Kinnon. Nilai statistik ADF atau PP ditunjukkan oleh nilai t statistik. Jika nilai absolut statistik ADF atau PP lebih besar dari nilai kritisnya, maka data yang diamati 
menunjukkan stasioner dan jika sebaliknya nilai statistik ADF atau PP lebih kecil dari nilai kritisnya maka data tidak stasioner.

\section{3. uji asumsi klasik}

Uji asumsi klasik digunakan untuk mendapatkan penduga koefisien regresi yang mempunyai error terkecil atau model regresi yangn dihasilkan adalah mempunyai sifat BLUE (Best Linier Unbiased Estimate) atau mempunyai sifat yang linier, tidak bias dan varian minimum. Adapun uji asumsi klasik adalah sebagai berikut:

\section{a. Uji Normalitas data}

Uji normalitas bertujuan untuk menguji apakah dalam model regresi variabel terikat dan variabel bebas keduanya mempunyai distribusi normal atau tidak.

\section{b. Uji Multikolinearitas}

Uji multikolinearitas bertujuan untuk melihat apakah model regresi yang digunakan atas korelasi antara variabel bebas. Model regresi yang baik seharusnya bebas multikolinearitas atau tidak terjadi kolerasi antara variabel independen. Syarat tidak terjadi Multikolinearitas adalah jika nilai korelasi antar variabel independen $<0,8$.

\section{c. uji heteroskedastisitas}

Uji heteroskedastisitas dilakukan dengan cara mellihat white heteroskedastisity test, dimana nilai probability Obs*R-squared $>0,05$ (alpha). Oleh karena itu nilai probability $O b s^{*} R$-squared $>0,05$ maka tidak terjadi heteroskedastisitas.

\section{d. Uji Autokorelasi}

Uji autokorelasi yang digunakan untuk mendeteksi adanya gejala otokolerasi adalah Durbin-Waston Statistic Test. Jika Durbin-Wastonnya antara -2 sampai 2 berarti tidak terjadi autokorelasi (Gujarti, 2003).

\section{Analisis Regresi Berganda}

Analisis regresi liner berganda bertujuan untuk membuktikan ada atau tidaknya hubungan fungsional antara tiga buah variabel bebas X (tingkat inflasi, suku bunga dan nilia kurs dollar AS) dari sebuah variabel terikat Y (IHSG). Dalam penelitian ini analisis tersebut digunakan untuk mengetahui. Seberapa besar variabel independen mempengaruhi variabel dependen dihitung dengan persamaan regresi berganda sebagai berikut :

$\mathrm{Y}=\mathrm{a}+\mathrm{bX} 1+\mathrm{bX} 2+\mathrm{bX} 3+\mathrm{e}$.

Keterangan :

$\mathrm{Y}=$ IHSG sektor pertambangan

(a) = Nilai Konstanta

(b) = Koefisien Regresi Berganda

$(\mathrm{X} 1)=$ tingkat inflasi

$(\mathrm{X} 2)=$ suku bnga

$(\mathrm{X} 3)=$ nilai kurs dollar AS

(e) $=$ Standart Error.

5. Uji hipotesis

a. Uji f (Silmutan)

Pengujian ini dilakukan untuk mengetahui apakah semua variabel bebas yang digunakan dalam model regresi secara bersama-sama berpengaruh terhadap 
variabel terikat dan tingkat kesalahan atau probabilitas yang diinginkan $\mathrm{P}=5 \%$ (Ghozali, 2010) :

\section{b. Uji t (Parsial)}

Pengujian secara parsial, dilakukan uji-t untuk menguji pengaruh masing masing variabel bebas terhadap variabel terikat dan tingkat kesalahan atau probabilitas yang diinginkan $\mathrm{P}=5 \%$ (Ghozali, 2005) :

\section{Koefisien Determinasi $\left(\mathbf{R}^{2}\right)$}

\section{HASIL PENELITIAN}

\section{Statistik Deskriptif Variabel Penelitian}

\section{Tabel 1}

Hasil Uji Deskripsi Statistik Variabel Penelitian

\begin{tabular}{|l|c|c|c|c|c|}
\hline Variabel & $\mathbf{N}$ & Minimum & Maksimum & Mean & $\begin{array}{c}\text { standar } \\
\text { deviasi }\end{array}$ \\
\hline X1 (Tingkat Inflasi) & 60 & 0.033500 & 0.087900 & 0.058852 & 0.015422 \\
\hline X2 (Suku Bunga) & 60 & 0.057500 & 0.077500 & 0.067750 & 0.007643 \\
\hline X3 (Nilai Kurs) & 60 & 8532.000 & 14396.10 & 10775.49 & 1760.346 \\
\hline Y (IHSG) & 60 & 3409.170 & 5518.670 & 4456.763 & 539.4253 \\
\hline
\end{tabular}

Sumber : Data Diolah

Dari Tabel 1 dapat dilihat bahwa tingkat inflasi memiliki nilai minimum sebesar 0.0335 dan nilai maksimum sebesar 0.0879. Nilai-nilai tersebut menunjukkan bahwa respon terhadap tingkat inflasi adalah antara 0.0335 sampai dengan 0.0879. Sementara standar deviasi tingkat inflasi sebesar 0.0154 lebih kecil dari nilai rata-rata yaitu 0,0588 menunjukkan bahwa tingkat suku bunga sebaran nilainya semakin dekat dari nilai rata-ratanya, yang mengidenitifikasi data tingat suku bunga tidak bervariasi.

Data tingkat suku bunga memiliki nilai minimum sebesar 0.0575 dan nilai maksimum sebesar 0.0775. Nilai-nilai tersebut menunjukkan bahwa respon terhadap tingkat suku bunga adalah antara 0.0575 sampai dengan 0.0775 . Sementara standar deviasi 0.0076 lebih kecil dari nilai rata-rata yaitu 0.0677 menunjukkan bahwa tingkat suku bunga sebaran nilainya semakin dekat dari nilai rata-ratanya, yang mengidenitifikasi data tingat suku bunga tidak bervariasi.

Data nilai kurs memiliki nilai minimum sebesar 8532.000 dan nilai maksimum sebesar 14396.10. Nilai-nilai tersebut menunjukkan bahwa respon terhadap kurs mata uang Rupiah atas Dollar AS adalah antara 8532.000 sampai dengan 14396.10. Sementara standar deviasi sebesar 1760.346 lebih kecil dari nilai rata-rata yaitu 10775.49 menunjukkan bahwa kurs mata uang Rupiah atas Dollar AS sebaran nilainya semakin dekat dari nilai rata-ratanya, yang mengidenitifikasi data kurs mata uang Rupiah atas Dollar AS tidak bervariasi.

Data Indeks Harga Saham Gabungan (IHSG) memiliki nilai minimum sebesar 3409.170 dan maksimum sebesar 5518.670. Nilai-nilai tersebur menunjukkan bahwa respon terhadap Indeks Harga Saham Gabungan (IHSG) adalah antara 3409.170 sampai dengan 5518.670 . Sementara standar deviasi sebesar 539.4253 lebih kecil dari nilai rata-rata yaitu 4456.763 menunjukkan 
bahwa Indeks Harga Saham Gabungan (IHSG) sebaran nilainya semakin dekat dari nilai rata-ratanya,

\section{Uji Stasioneritas}

Tabel 2

Hasil Uji Stasioneritas

\begin{tabular}{|c|c|c|c|}
\hline \multirow{2}{*}{ Variabel } & \multicolumn{3}{|c|}{ Tingkat Stasioneritas } \\
\cline { 2 - 4 } & \multicolumn{3}{|c|}{ Level } \\
\cline { 2 - 4 } & t-statistic & Probability & Keterangan \\
\hline X1 & -5.0199 & 0.0001 & Stasioneritas \\
\hline X2 & -7.5092 & 0.0000 & Stasioneritas \\
\hline X3 & -6.1347 & 0.0000 & Stasioneritas \\
\hline Y & -6.8716 & 0.0000 & Stasioneritas \\
\hline
\end{tabular}

Sumber: Data Diolah

Pada tabel 2 diatas menunjukkan bahwa semua variabel baik independen maupun dependen telah stasioner dengan test for unit root in "level". Level yang dipakai pada uji stasioneritas adalah level 5\% karena persyaratan probabilitynya $<5 \%$.

\section{Uji Asumsi Klasik}

a. Uji Normalitas data

\section{Tabel 3}

Hasil Uji Normalitas Data

\begin{tabular}{|l|c|c|c|c|}
\hline \multicolumn{1}{|c|}{ Variabel } & N & Jarque-Bera & Probability & Keterangan \\
\hline X1 (Tingkat Inflasi) & 60 & 4.002683 & 0.135154 & Nornal \\
\hline X2 (Suku Bunga) & 60 & 5.112295 & 0.077603 & Normal \\
\hline X3 (Nilai Kurs) & 60 & 5.257625 & 0.072164 & Normal \\
\hline Y (IHSG) & 60 & 2.463306 & 0.291810 & Normal \\
\hline
\end{tabular}

Sumber: data diolah

Berdasarkan tabel 3 hasil dapat dilihat bahwa semua variabel baik dependen maupun independen telah terdistribusi normal. Karena nilai signifikan lebih dari 0,05 , sehingga data dalam penelitian ini dapat disimpulkan sudah berdistribusi normal memenuhi syarat model regresi karena sudah normal.

\section{b. Uji Multikolinearitas}

Tabel 4

Hasil Uji Normalitas Data

\begin{tabular}{|c|c|c|c|}
\hline & $\mathrm{X} 1$ & $\mathrm{X} 2$ & $\mathrm{X} 3$ \\
\hline $\mathrm{X} 1$ & 1.000000 & -0.601646 & 0.432953 \\
\hline $\mathrm{X} 2$ & -0.601646 & 1.000000 & -0.793407 \\
\hline $\mathrm{X} 3$ & 0.432953 & -0.793407 & 1.000000 \\
\hline
\end{tabular}

Sumber: Data Diolah

Berdasarkan hasil olahan data pada Tabel 4 terlihat nilai kolerasi antara sesama variabel independen $<0,8$ sehingga dapat dikatakan bahwa sesama variabel independen tidak memiliki hubungan multikolinearitas. 


\section{c. Uji Autokolerasi}

Tabel 5

Hasil Uji Durbin-Watson

\begin{tabular}{|c|c|}
\hline Model & Durbin watson \\
\hline 1 & 0.247698 \\
\hline
\end{tabular}

Sumber: Data Dioalah

Dari uji Darbin-Watson pada Tabel 5 terlihat bahwa tidak terjadi otokolrasi karena nilai Durbin-Watson antara $-2<0.247698<2$.

d. Uji Heteroskedastisitas

Tabel 6

Hasil Uji Heteroskedastisitas

\begin{tabular}{|ccll|}
\hline F-statistic & 0.733262 & Probability & 0.6162 \\
\hline Obs*R-squared & 0.999841 & Probability & 0.6486 \\
\hline
\end{tabular}

Sumber: Data Diolah

Pada tabel 6 terlihat tidak terjadi heteroskedastisitas karena nilai probability Obs*R-squared yaitu $0.6486>0,05$.

4. Analisis Regresi Linier Berganda

\section{Tabel 7}

Hasil Uji Regresi Linier Berganda

Dependent Variable: Y

Method: Least Squares

Date: 11/14/16 Time: 11:44

Sample: 2011M01 2015M12

Included observations: 60

\begin{tabular}{crlll}
\hline \hline \multicolumn{1}{c}{ Variable } & Coefficient & Std. Error & t-Statistic & Prob. \\
\hline \hline C & -24.39461 & 106.7778 & -0.228461 & 0.8201 \\
X1 & -11.32092 & 44.02475 & -0.257149 & 0.7980 \\
X2 & -24.62072 & 106.7590 & -0.230620 & 0.0485 \\
X3 & 0.217184 & 0.050613 & 4.291064 & 0.0001 \\
\hline \hline R-squared & 0.438689 & Mean dependent var & 4456.763 \\
Adjusted R-squared & 0.408619 & S.D. dependent var & 539.4253 \\
S.E. of regression & 414.8252 & Akaike info criterion & 14.95793 \\
Sum squared resid & 9636475. & Schwarz criterion & 15.09755 \\
Log likelihood & -444.7380 & Hannan-Quinn criter. & 15.01255 \\
F-statistic & 14.58881 & Durbin-Watson stat & 0.247698 \\
Prob(F-statistic) & 0.000000 & & \\
\hline \hline
\end{tabular}

Sumber : Data Eviews

Dari tabel 7 diatas, dapat dituliskan persamaan sebagai berikut:

$\mathrm{Y}=-243,9461-11,32092$ X1 - 24,62072 X2 + 0,217184 X3 + e. Dimana nilai konstanta sebesar -24,39461. Nilai koefisien ini menunjukkan jika tidak ada 
perubahan pada variabel tingkat inflasi, suku bunga dan kurs rupiah maka IHSG akan mengalami penurunan sebesar 24,39461 poin.

Ini menunjukkan koefisien kolerasi Tingkat Inflasi (X1) sebesar -11,32092. Tanda negatif menunjukkan arah berlawanan atau berbanding terbalik. Jika variabel tingkat inflasi meningkat $1 \%$ maka IHSG akan mengalami penurunan sebesar 11,32092 poin, dan sebaliknya apabila tingkat inflasi menurun $1 \%$ maka IHSG akan mengalami peningkatan sebesar 11,32092 poin.

Koefisien kolerasi Suku Bunga (X2) sebesar -24,62072. Tanda negatif menunjukkan arah berlawanan atau berbanding terbalik. Jika variabel tingkat suku bunga meningkat $1 \%$ maka IHSG akan mengalami penurunan sebesar 24,62072 poin, dan sebaliknya apabila tingkat inflasi menurun $1 \%$ maka IHSG akan mengalami peningkatan sebesar 24,62072 poin.

\section{Uji Hipotesis}

\section{a. Uji Koefisiensi Regresi Secara Simultan ( Uji f)}

Dari tabel 7 dihasilkan nilai $F$-statistic sebesar 14.58881 dengan nilai signifikan probability $F$-statistic adalah 0.000000 , tingkat probabilitasnya lebih kecil dari 0,05 atau <0,05. Hal tersebut mengidentifikasi bahwa semua variabel independen (X1,X2 dan $\mathrm{X} 3$ ) berpengaruh secara signifikan terhadap variabel dependen (IHSG).

\section{b. Uji Koefisiensi Regresi Secara Parsial (Uji t)}

Dari hasil pengolahan data dihasilkan tingkat inflasi menunjukkan $t_{\text {hitung }}$ 0,257149 dengan nilai yang tidak signifikan 0,7980 lebih dari tingkat alpha 0,05 dan koefisien $\beta$ sebesar $-11,32092$ menunjukkan nilai negatif. Hal ini berarti bahwa tingkat inflasi berpengaruh negatif dan tidak signifikan terhadap indeks harga saham gabungan (IHSG).

Suku bunga menunjukkan $t_{\text {hitung }}-0,230620$ dengan nilai yang signifikan 0,0485 kecil dari alpha 0,05 dan koefisien $\beta$ sebesar -24,62072 menunjukkan negatif. Hal ini berarti bahwa suku bunga berpengaruh negatif dan signifikan terhadap Indeks Harga Saham Gabungan (IHSG).

Sedangkan untuk nilai kurs menunjukkan $t_{\text {hitung }}$ 4,291064 dengan nilai yang signifikan 0,001 kecil dari alpha 0,05 dan koefisien $\beta$ sebesar 0,217184 menunjukkan positif. Hal ini berarti bahwa nilai kurs berpengaruh positif dan signifikan terhadap Indeks Harga Saham Gabungan (IHSG).

\section{c. Koefisien Determinasi $\left(\mathbf{R}^{2}\right)$}

Dari hasil pengolahan data ditemukan nilai $R$-Square 0.408619 ini berarti bahwa variabel bebas X1 (Tingakt Inflasi),X2 (Suku Bunga) dan X3 (Nilai Kurs) mempengaruhi IHSG (Indeks Harga Saham Gabungan) sebesar 40,86\% sedangkan sisanya 59,14\% dipengaruhi oleh faktor lain.

\section{PEMBAHASAN}

\section{Pengaruh Tingkat Inflasi terhadap Indeks Harga Saham Gabungan}

Dari Tabel 7 dihasilkan nilai koefisien regresi untuk variabel tingkat inflasi yang diproxy oleh (IHSG) sebesar -11,32092 bertanda negatif dengan nilai probability $0.7980>0,05$ yang berarti bahwa inflasi mempunyai pengaruh negatif dan tidak signifikan terhadap probabilitas yang diproxy oleh IHSG (Indeks Harga 
Saham Gabungan). Dengan demikian dapat disimpulkan hipotesis pertama ditolak.

Tidak signifikannya pengaruh inflasi pada penelitian ini dikarenakan selama periode pengamatan tingkat inflasi berada dalam katergori inflasi ringan berkisar pada 3,35\% sampai 8,37\% atau bisa dikatakan bahwa tingkat inflasi masih dibawah $10 \%$. Namun, bila inflasi menembus angka $10 \%$, maka pasar modal akan terganggu.

Hal ini menandakan bahwa tingkat inflasi tidak berpengaruh banyak terhadap keputusan investor dalam menanamkan modalnya pada periode pengamatan dikarenakan tidak adanya pengaruh yang signifikan antara tingkat inflasi dengan IHSG.

Penelitian ini mempunyai hasil yang sama dengan penelitian yang dilakukan oleh Kumalasari, dkk. (2016) melakukan penelitian tentang Pengaruh Nilai Tukar, Bi Rate, Tingkat Inflasi dan Pertumbuhan Ekonomi terhadap Indeks Harga Saham Gabungan dimana tingkat inflasi berpengaruh negatif dan tidak signifikan terhadap Indeks Harga Saham Gabungan (IHSG).

Penelitian ini juga didukung oleh penelitian yang dilakukan Kewal (2012) melakukan penelitian tentang Pengaruh Inflasi, Suku Bunga, Kurs dan Pertumbuhan PDB terhadap Indeks Harga Saham Gabungan yang menemukan bahwa Tingakt Inflasi berpengaruh negatif dan tidak signifikan terhadap IHSG.

\section{Pengaruh Suku Bunga terhadap Indeks Harga Saham Gabungan}

Dari Tabel 7 dihasilkan nilai koefisien regresi untuk variabel Suku Bunga yang diproxy oleh IHSG (Indeks Harga Saham Gabungan) sebesar -246,2072 bertanda negatif dengan nilai probability $0.0485<0,05$ yang berarti bahwa suku bunga mempunyai pengaruh negatif signifikan terhadap IHSG (Indeks Harga Saham Gabungan). Dengan demikian dapat disimpulkan hipotesis kedua diterima.

Tanda negatif pada koefesien menunjukkan adanya pengaruh yang berlawanan. Apabila tingkat suku bunga naik, maka IHSG akan turun, dan sebaliknya apabila tingkat suku bunga turun maka IHSG akan naik. Pengaruh negatif yang diberikan variabel tingkat suku bunga terhadap IHSG sesuai dengan pendapat Tandelin (2010) yang menyebutkan bahwa suku bunga mempengaruhi harga saham secara terbalik (cateris paribus).

Apabila tingkat suku bunga naik maka return investasi dalam bentuk perbankan akan naik sehingga banyak investor menjual sahamnya dan beralih pada investasi pada sektor perbankan baik dalam bentuk tabungan maupun deposito. Hal ini menyebabkan penurunan pada harga saham dan IHSG.

Hasil penelitian ini sama dengan penelitian yang dilakukan oleh Maurina, dkk. (2015) yang berjudul Pengaruh Tingkat Inflasi, Kurs Rupiah dan Tingkat Suku Bunga Bi Rate terhadap IHSG menunjukkan terdapat pengaruh negatif dan signifikan antara tingkat suku bunga BI Rate terhadap IHSG.

\section{Pengaruh Nilai Kurs Dollar AS terhadap Indeks Harga Saham Gabungan}

Dari Tabel 7 dihasilkan nilai koefisien regresi untuk variabel Nilai Kurs yang diproxy oleh IHSG (Indeks Harga Saham Gabungan) 0.217184 bertanda positif dengan nilai probability $0.0001<0,05$ yang berarti bahwa nilai kurs mempunyai 
pengaruh positif dan signifikan terhadap IHSG (Indeks Harga Saham Gabungan). Dengan demikian dapat disimpulkan hipotesis ketiga diterima.

Pengaruh positif yang diberikan variabel kurs rupiah terhadap IHSG menujukkan bahwa penguatan kurs US dollar (rupiah terdepresiasi) justru akan meningkatkan IHSG. Hal ini terjadi karena penurunan nilai tukar rupiah mengakibatkan makin murahnya produk ekspor asal Indonesia di pasar mancanegara. Hal ini akan menyeabkan meningkatnya permintaan akan produk ekspor indonesia. Hal ini dapat membuat pengeluaran agregat atas output dapat meningkat, persedian menurun, dan PDB riil akan meningkat. Maka dapat disimpulkan bahwa depresiasi mata uang suatu negara cenderung meningkatkan PDB negara tersebut dan kenaikan PDB ini dapat mendorong kenaikan investasi di dalam negeri, sehingga hal ini juga dapat mendorong kenaikan IHSG.

Kenaikan tingkat kurs juga dapat mendorong kenaikan tingkat harga. Menurut Case dan Fair (2007) kenaikan mata uang suatu negara cenderung meningkatkan tingkat harganya. Ada dua alasan efek ini terjadi. Pertama, ketika mata uang suatu negara lebih murah, produknya lebih kompetitif di pasar dunia, sehingga ekspor naik. Di samping itu, pembeli domestik cenderung mensubtitusi barang (impor yang lebih) dengan produk domestik. Oleh karena itu, pengeluaran agregat yang direncanakan pada barang dan jasa buatan dalam negeri naik. Hasilnya adalah tingkat harga yang lebih tinggi, output yang lebih tinggi, atau keduanya. Kedua, depresiasi membuat input yang diimpor lebih mahal.

Hasil penelitian ini sama dengan penelitian yang dilakukan oleh Palatte dan Akbar yang berjudul Pengaruh Nilai Tukar Mata Uang Dan Tingkat Suku Bunga Terhadap Perkembangan Indeks Harga Saham Gabungan Di Bursa Efek Indonesia Periode 2009-2013 menunjukkan terdapat pengaruh positif dan signifikan terhadap Indeks Harga Saham Gabungan.

\section{SIMPULAN}

1. Hasil uji $\mathrm{F}$ (simultan) menunjukkan bahwa semua variabel independen berpengaruh secara signifikan terhadap variabel dependen (IHSG). Hasil uji t (parsial) menunjukkan bahwa hanya nilai tukar dan suku bunga yang berpengaruh signifikan terhadap IHSG, dimana nilai tukar berpengaruh positif dan suku bunga berpengaruh negatif, sedangkan inflasi tidak signifikan terhadap IHSG. Koefisien determinasi dalam penelitian ini adalah sebesar $40,86 \%$ sedangkan sisanya $100 \%-40,86 \%=59,14 \%$ dipengaruhi oleh faktor lain.

2. Tingkat inflasi berpengaruh negatif dan tidak signifikan Indeks Harga Saham Gabungan (IHSG).

3. Tingkat suku bunga berpengaruh negatif dan signifikan terhadap indeks harga saham gabungan.

4. Nilai kurs berpengaruh positif dan signifikan terhadap IHSG (Indeks Harga Saham Gabungan). 


\section{DAFTAR PUSTAKA}

Afriyeni, A., \& Marlius, D. (2017). Analisis Pengaruh Harga Saham Perdana Terhadap Abnormal Return Yang Diterima Investor Studi Pada Bursa Efek Indonesia. https://doi.org/10.31219/osf.io/8z7hx

Afriyeni, A., \& Marlius, D. (2018). Analisis Pengaruh Informasi Prospektus Perusahaan Terhadap Initial Return Saham Pada Pasar Perdana Di Bursa Efek Indonesia. https://doi.org/10.31219/osf.io/kt6c4

Ang, Robbert.1997, “Pasar Modal Indonesia”. Mediasoft Jakarta.

Case dan Fair. 2007. "Prinsip-Prinsip Ekonomi". Edisi 8 Jilid 2. Jakarta: Erlangga. Lembaga Penerbit Fakultas Ekonomi Universitas Indonesia

Hartono, jogiyanto. 2013 "Teori Portofolio Dan Analisis Investasi". Edisi kedelapan. Yogyakarta: BPEE

Ghozali, Imam. 2005. Aplikasi Analisis Multivariate Dengan Program SPSS. Semarang: Badan Penerbit Universitas Diponegoro.

Gujarati, Damodar. 2003. Ekonometrika Dasar. Erlangga: Jakarta.

Kewal, Suramaya suci. 2012."Pengaruh Inflasi, Suku Bunga, Dan Pertumbuhan PDB Terhadap Indeks Harga Saham Gabungan”. Jurnal ekonomi. Volume 8. Nomor 1. April 2012

Kuncoro, mudrajad. 2001. Metode Kuantitatif Teori Dan Aplikasi Untuk Bisnis Dan Ekonomi. Edisi 1, Cetakan 1 Unit Penerbitan Dan Percetakan AMP YKPN, Yogyakarta.

Maurina. Yenita, R. Rustam Hidayat, Sri Sulasmiyati. 2015. "Pengaruh Tingkat Inflasi, Kurs Rupiah Dan Tingkat Suku Bunga BI Rate Tetrhadap IHSG (Studi Pada Bursa Efek Indonesia Periode 2010-2014)”. Jurnal administrasi bisnis (JAB). Vol. 27 No.2 Oktober 2015.

Palatte, Muh.Halim dan Akbar. 2014. "Pengaruh Nilai Tukarmata Uang Dan Tingkat Suku Bunga Terhadap Perkembangan Indeks Harga Saham Gabungan Di Bursa Efek Indonesia Periode 2009-2013”. Jurnal Manajemen. Vol. 01 No.02. Juli 2014

Putong, Iskandar. 2002.” Ekonomi mikro \& makro”. Edisi 2. Ghalia Indonesia

Sukirno, Sadono. 2010. Makro Ekonomi Teori Pengantar. Edisi Ketiga. Jakarta: Kelapa Gading.. 
Tandelin, Eduardus. 2010 “Potofolio Dan Investasi Teori Dan Aplikasi”.'Edisi pertama.Penerbit KANISIUS Yogyakarta.

http://www.finance.yahoo.com

www.bi.go.id

www.bps.go. 